Georgia State University

ScholarWorks @ Georgia State University

8-3-2012

\title{
Library Technical Services: Key Ingredients in the Recipe for a Successful Institutional Repository
}

Tammy Sugarman

Georgia State University, tsugarman@gsu.edu

Follow this and additional works at: https://scholarworks.gsu.edu/univ_lib_facpres

Part of the Library and Information Science Commons

\section{Recommended Citation}

Sugarman, Tammy, "Library Technical Services: Key Ingredients in the Recipe for a Successful Institutional Repository" (2012). University Library Faculty Presentations. 23.

https://scholarworks.gsu.edu/univ_lib_facpres/23

This Presentation is brought to you for free and open access by the Georgia State University Library at ScholarWorks @ Georgia State University. It has been accepted for inclusion in University Library Faculty Presentations by an authorized administrator of ScholarWorks @ Georgia State University. For more information, please contact scholarworks@gsu.edu. 


\section{Library Technical Services: Key Ingredients in the Recipe for a \\ Successful Institutional Repository MSU LEETS \\ August 3, 2012}

http://digitalarchive.gsu.edu/univ lib facpres/23/

Tammy S. Sugarman

Georgia State University Library 


\section{With apologies to the Food Network...}

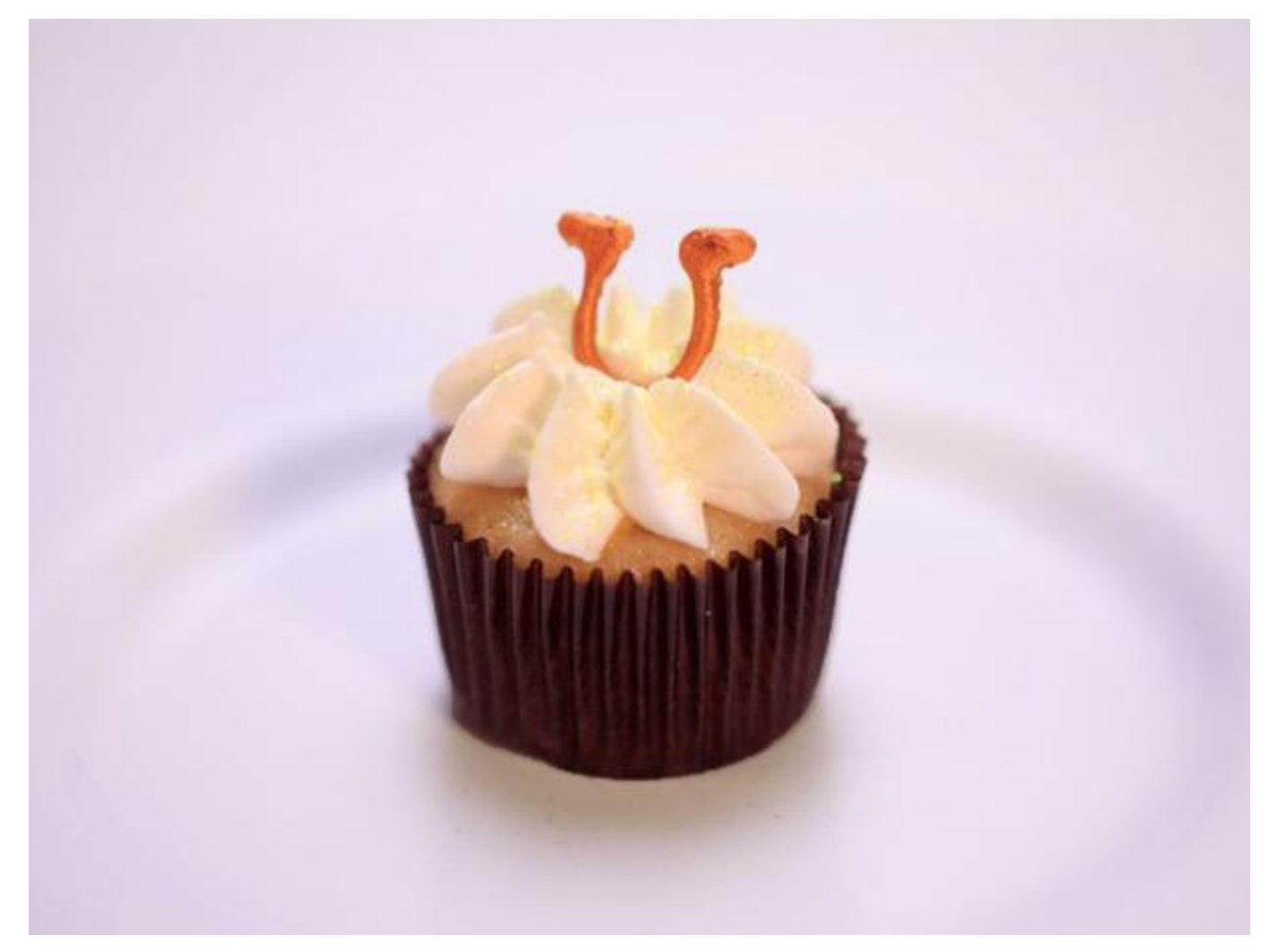

IR Cupcake Wars!

(with a slightly different outcome) 


\section{Our Show...}

- Theme

- Ingredients

- Bakers

- Baking Process

- "Virtual Tasting" 


\section{Theme}

Institutional Repository

"A set of services that a university offers to the members of its community for the management and dissemination of digital materials created by the institution and its community members."

-Clifford Lynch 


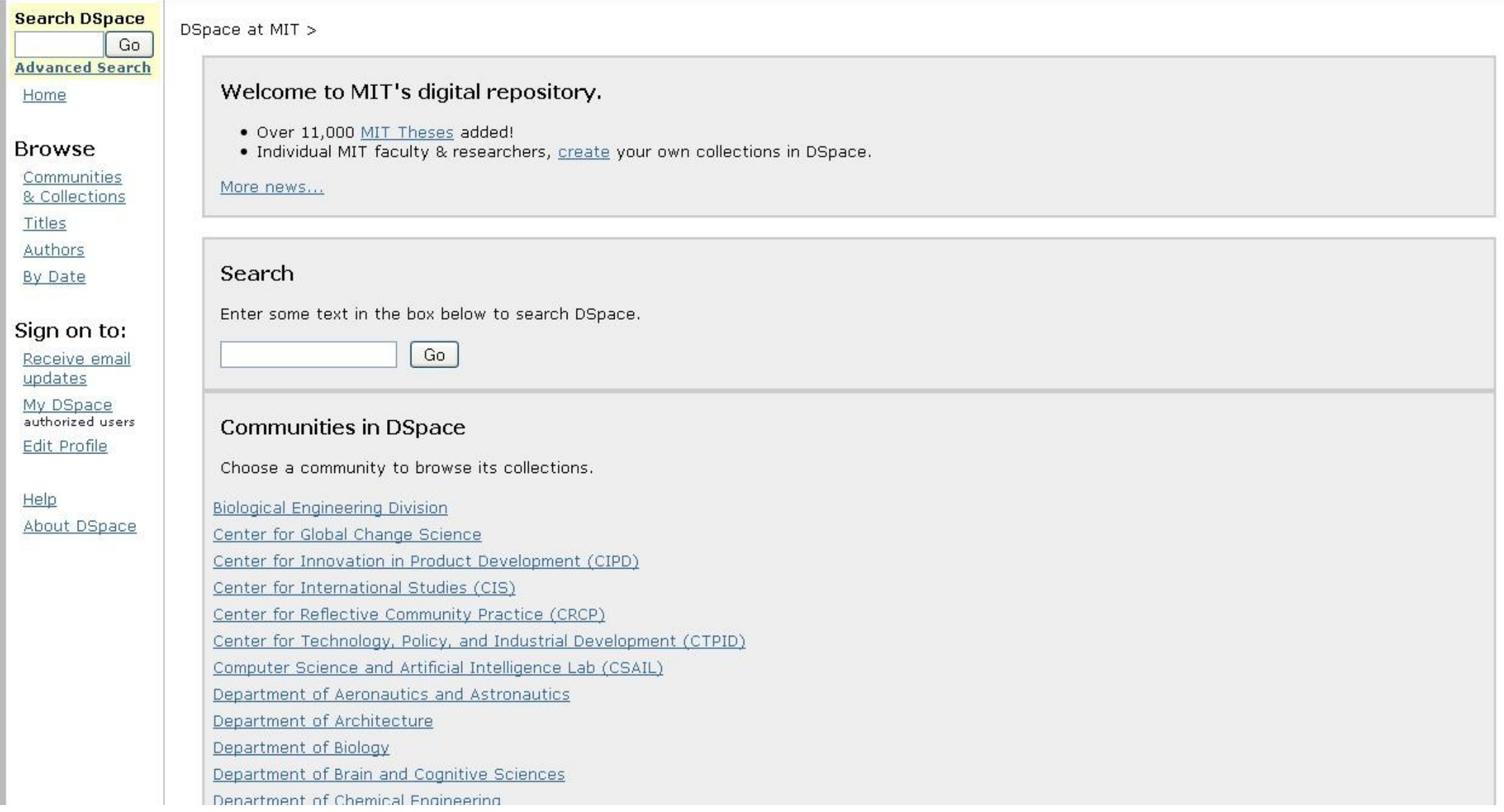

What's in DSpace?...

MIT Research in

digital form,

including preprints

technical reports,

working papers,

theses,

conference

papers, images,

and more.

\section{Is this all}

of MIT's

research?...

No. DSpace is limited to digital research products. For items in print, go to Barton: MIT go to Barton: MIT DSpace is young and growing rapidly. Check back often. 
Search DSpace@MIT Go

\section{Advanced Search}

Browse

All of DSpace@MIT Communities \& Collections By Issue Date Authors Titles Subjects

\section{My Accoun}

Login

Reqiste

Links

About DSpace@MIT RSS 1.0

Welcome to DSpace@MIT, MIT's institutional repository built to save, share, and search MIT's digital research materials including an increasing number of conference papers, images, peer-reviewed scholarly articles, preprints, technical reports, theses, working papers, and more. For research materials in print form, please go to Barton: MIT Libraries' catalog.

\section{Search}

\section{Communities}

Select a community to browse its collections.

Abdul Latif Jameel Poverty Action Lab (J-PAL)

Air Transportation Research

Auto-ID Laboratory

Biological Enqineering Division

Center for Advanced Nuclear Eneray Systems (CANES)

Center for Eneray and Environmental Policy Research

Center for Global Chanqe Science

Center for Grid Computing

Center for Innovation in Product Development (CIPD)

Center for International Studies (CIS)

Center for Reflective Community Practice (CRCP)

Comparative Media Studies

Computational and Systems Biology

Computer Science and Artificial Intelliqence Lab (CSAIL)

Department of Aeronautics and Astronautics

Department of Architecture

Department of Biology

Department of Brain and Cognitive Sciences

Department of Chemical Enqineering

Department of Chemistry

Department of Civil and Environmental Enqineering

Department of Earth, Atmospheric, and Planetary Sciences

Department of Economics

\section{Latest News}

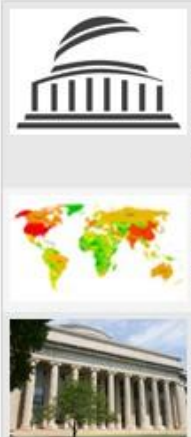

MIT Open Access Articles

DSpace@MIs Open Access Articles collection contains over 5,000 scholarly articles that MIT Faculty have made openly avalable on the web under their Open Access Policy. Articles have been vewed more than 380,000 times since the collection was launched in October 2009. [Updated March 2012] I More information about the policy | Submit a paper | Browse the collection

Celebrating three years of the MIT Faculty Open Access Policy In the 3 years since the establishment of the Policy, articles in the Open Access Articles Collection have been downloaded at a rate that has grown to more than 30,000 per month, with requests from nearly every country in the world.

MIT Thesis Collection Tops 30,000 DSpace@MIT contains selected digital theses and dissertations from all MIT departments dating as far back as the mid-1800s. Since 2004, all new Masters and Ph.D theses have been added to the collection after degrees have been awarded. Browse the collection

15.2 million downloads in FY2010 Usage of DSpace@MIT continues to dramatically increase as our collections and readership grow. Analysis of usage statistics for last fiscal year indicates that DSpace@Mir content was rate of 41,000 files per day contact us to set up a collection for research group. 


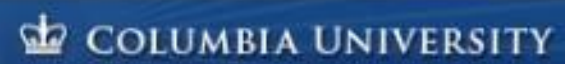 ACADEMIC COMMONS}

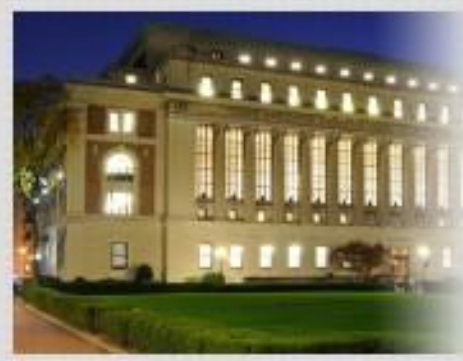

Academic Commons is Columbia University's digital repository where faculty, students, and staff of Columbia and its affiliate institutions can deposit the results of their scholarly work and research. Content in Academic Commons is freely available to the public.

Login | History

\section{BROWSE AC CONTENT}

\section{DEPARTMENTS}

SUBJECTS

\section{HELPFUL LINKS}

\section{DEPOSIT YOUR RESEARCH} ABOUT ACADEMIC COMMONS FAQ/ASK A QUESTION

\section{AC BY THE NUMBERS}

7255 items in Academic Commons. Objects added in the last year: $\mathbf{3 2 5 9}$ Objects added in the last 30 days: $\mathbf{5 4 4}$ Page Visits in June: $\mathbf{8 4 7 7}$

\section{New in Academic Commons:}

An overview of cligital audio
Jaggars, Damon $E$.

Foreword to "Planning and Implementing Discovery Tools in Academic Libraries"

Research on couple-based risk reduction interventions for men who have sex with men (MSM): Lessons learned about methodological and practical challenges

Wu, Elwin Hess, Leona et al.
Statically Unrolling Recursion to Improve Opportunities for Parallelism

Deshpande, Neil Edwards, Stephen A.

Comparing Simulations and Observations of Galaxy Evolution: Methods for Constraining the Ilature of Stellar Feedback 


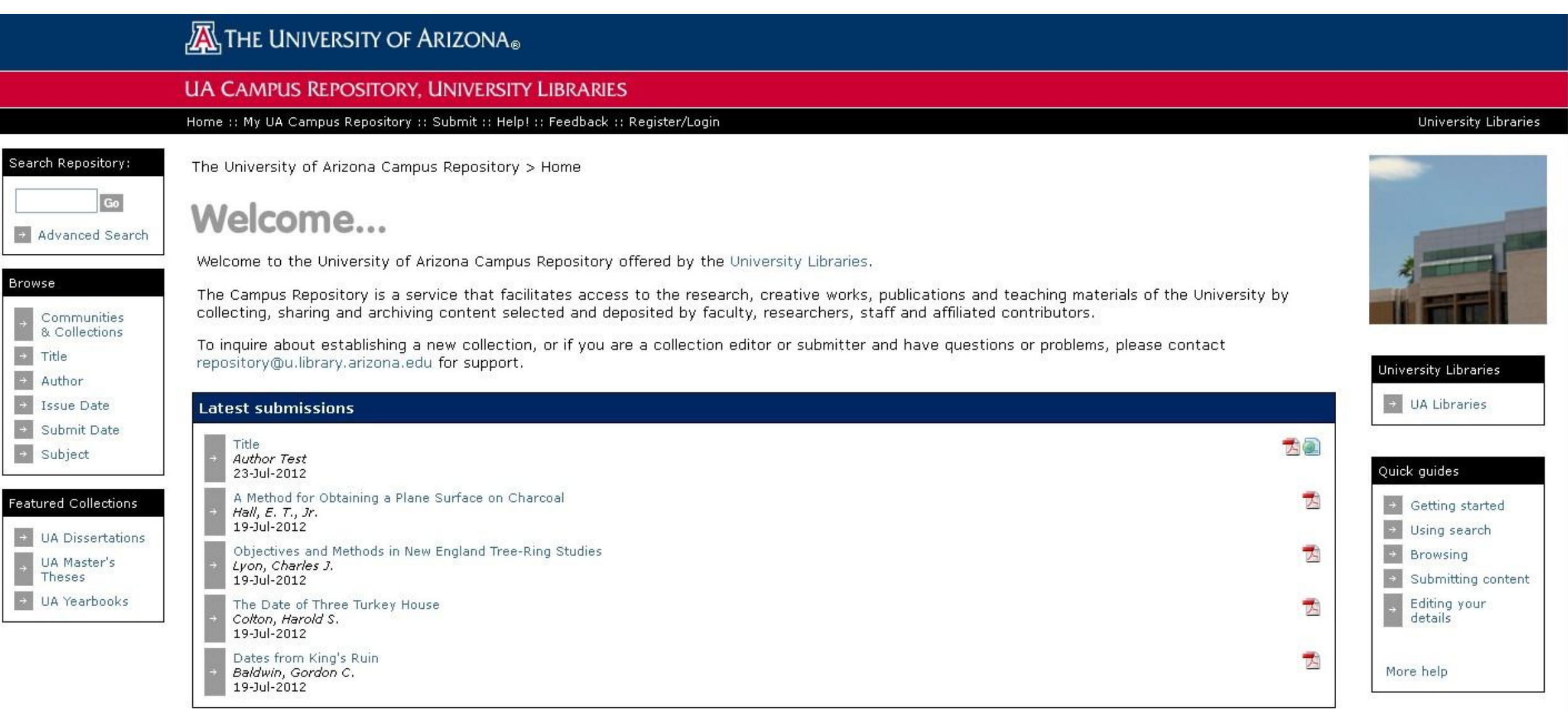




\section{Browse Research and Scholarship}

College, School or Department

SelectedWorks Gallery

Journals and peer-reviewed series

\section{Faculty Publications}

$\square$ Theses and Dissertations

\section{Conferences}

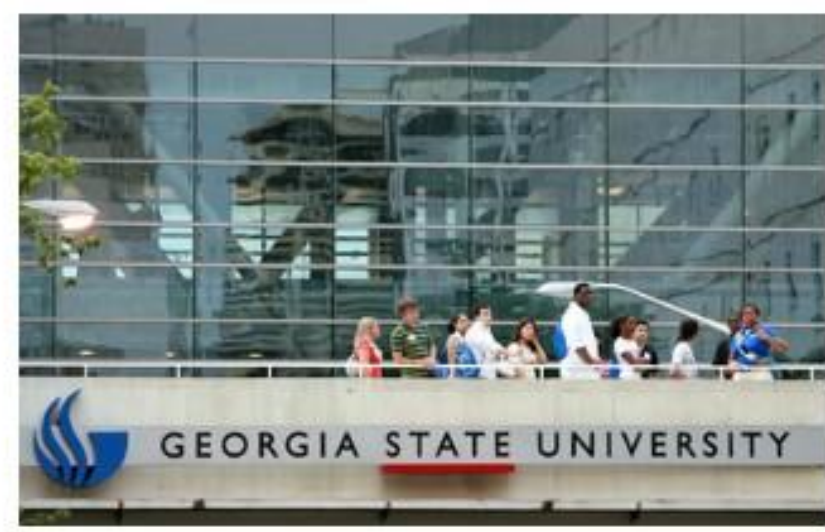

The Digital Archive $@$ Georgia State University highlights the research and scholarly productivity of members of the University community. The University Library administers the archive to collect, organize, disseminate, and preserve the digital scholarly output of Georgia State University faculty, students and staff.

\section{At a Glance}

\section{Top 10 Downloads}

All time

\section{Paper of the Day}

Race Scholars on the Politics of Race, Research, and Risk: A Narrative Inquiry Sibby Anderson-Thompkins
Enter search terms:

in this repository $\quad v$

Advanced Search

Notify me via email or RSS

\section{Browse}

Collections

Disciplines

Authors

\section{Authors}

Faculty Submission Information

Copyright Overview

Author FAQ

ETD Submission Information

Submit ETD (ThesisiDissertation)

\section{SelectedWorks}

Login to SelectedWorks

Start a SelectedWorks Site

What is SelectedWorks? 


\section{Scholarly communication in the 21 st century Trends and Issues}

Topics covered by the panelists will include information archiving and dissemination (open archives, institutional repositories, book digitizing projects, etc.); electronic publishing; quality control; intellectual property and copyright; and the implications of these and other trends for reading and democracy, quality control, promotion and tenure of faculty, and traditional means of scholarly communication.

\section{Or Browse By:}

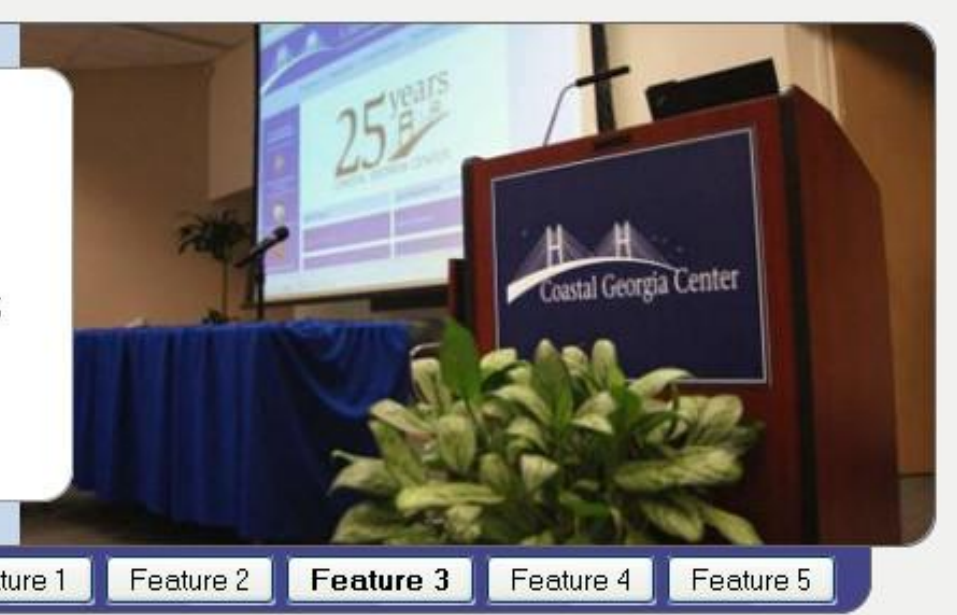

\section{http://www.gaknowledge.org//}




\section{Ingredients}

- Electronic Theses \& Dissertations

- Scholarly articles

Most

Common

- Annual reports

- Pre-prints; Post-prints

- Working papers; White papers

- Undergraduate Research Journals

- Conference papers, proceedings

- The "unique content" of the institution whatever that may be 


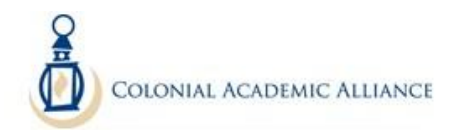

Colonial Academic Alliance

Undergraduate Research Journal

Home $>$ CA.AURJ

Journal Home

About this Journal

Aims \& Scope

CAA Undergraduate Research Journal

The Colonial Academic Alliance develops, promotes and facilitates

collaborative programs and resource sharing to enhance academic quality

and institutional effectiveness throughout our member institutions.

The Colonial Academic Alliance Undergraduate Research Journa

publishes undergraduate research in all fields by students at these

institutions.

Current Volume: Volume 2 (2011)

$\triangle \mathrm{PDF} \quad$ The Adoption of Christianity by the Irish and Anglo-Saxons: The Creation of Two Different Christian Societies Thomas Mart:

$\triangle \mathrm{PDF} \quad$ On the Color Line: The Early Ideologies and Methodologies of Dr. W.E.B. Du Bois

Editorial Board

Policies

Submit Article

Most Popular Papers

Receive Custom Email Notices or RSS

Select a volume:

All Issues $\vee$ Browse

Enter search terms:

\begin{tabular}{|l|}
\hline in this journal \\
\hline
\end{tabular}

Advanced Search

$\triangle \mathrm{PDF} \quad$ Discovering Multicultural Connections Virginia L. Driggers 


\section{http://digitalarchive.gsu.edu/caaurj/}

\section{On the Color Line: The Early Ideologies and Methodologies of Dr. W.E.B. Du Bois}

Alexis M. Rogers, Georgia State University

\section{Faculty Mentor}

Dr. Glenn T. Eskew

\section{Abstract}

William Edward Burghardt Du Bois' over 70 year long career has been critiqued and referenced in regards to the subject of American history, African American history, and more specifically, the struggle for civil rights and equality since the turn of the Twentieth Century. Du Bois' early thoughts and theories on the plight of the African American community were pivotal in the eventual success of his campaign for African American suffrage and equality in all aspects of American society. The study of these original theories and methods, spanning for around 1897 to his resignation from the NAACP in 1934, provides a more intimate look at what serves as the foundational ideologies for the modern Civil Rights Movement and the individual who lived by them. Using only materials read by or written by Du Bois, himself, the research done and evidence found suggest a more progressive side of the intellectual. Addresses, publications, personal diary entries, and letters of correspondence all reveal the personal struggles and thoughts of the man and the unique strategies implemented to successfully solve what Du Bois describes as "the Negro problem" of the Twentieth Century American South. Du Bois' vital emphasis on education, industry, and politics sets him apart from his equally steadfast counterparts questioning the most effective strategies in regards to public opinion, leadership, and civil rights

\section{Recommended Citation}

Rogers, Alexis M. (2011) "On the Color Line: The Early Ideologies and Methodologies of Dr. W.E.B. Du Bois," Colonial Academic Alliance Cholergraduate Research Joumal: Vol. 2, Article 2.

Available at: http://digitalarchive.gsu.edu/caaurjorol $2 / i s s 1 / 2$
Journal Home

About this Journal

Aims \& Scope

Editorial Board

Policies

Submit Article

Download Adobe Reader $A$

Most Popular Papers

Receive Custom Email Notices or RSS

Select a volume:

All Issues $\quad \checkmark$ Browse

Enter search terms:

\begin{tabular}{|l|}
\hline \\
\hline in this journal $\quad \checkmark$ \\
\hline
\end{tabular}

Advanced Search

ISSN: $2165-7076$ 

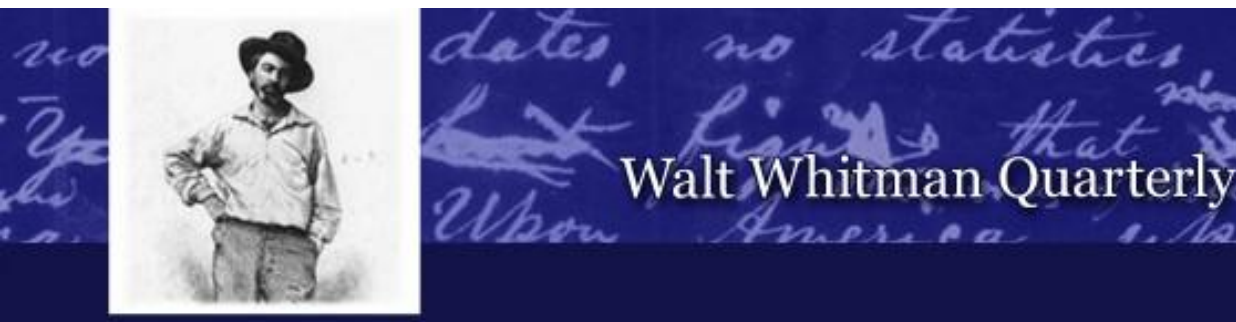

Whow Walt Whitman Quarterly Review

a. Dan.

Sas.

Home

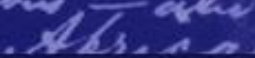

$2+.29$

About Policies

My Account

Journal Home

About this Journal

Aims \& Scope

Editorial Board

Policies

Subscriptions

Announcements

Reviews

Walt Whitman Archive

Whitman Bibliography

Gallery of Images

Census of the 1855 Leaves of Grass

Submit Article

Most Popular Papers

Receive Custom Email Notices or RSS

Select an issue:

All Issues

Browse

\section{Enter search terms:}

in this journal v

MNOR

The Wait Whitman Quartery Review is a literary quarterly sponsored by the Graduate Colleqe and the Department of English and published by The University of lowa. WWQR is the official journal of the Walt Whitman Studies Association, affiliated with the American Literature Association.

Subscribers may send their email address or IP range to lib-ir@uiowa.edu in order to access the current year.

Current Issue: Volume 29, Number 4 (2012) Special Focus: Whitman's Influence Number Four Spring 2012

Full text of this issue is restricted to subscribers.

\section{Front Matter}

$\triangle \mathrm{PDF} \quad$ Front Matter

\section{Essays}

$\angle$ PDF Robert Henri, Walt Whitman, and the American Artist p. 131-151 Ruth L. Bohan

\&PDF The Korean Adam: Yi Hyoseok and Walt Whitman p. 152-158 Steven D. Capener

$\triangleq \mathrm{PDF} \quad$ Walt Whitman, Clarence Major, and Changing Thresholds of American Wonder p. 159-170 Linda Furgerson Seizer

Reviews

\section{ABOUT THIS IMAGE}

John Sloan, Horace L. Traubel

(1858-1919), 1916. Oil on canvas, $32 \times 26$

in. $(81.3 \times 66.0 \mathrm{~cm}$.). Acc. No.: 1977.14 .

Courtesy of the Pennsylvania Academy of the Fine Arts, Philadelphia. Gift of Helen Farr Sloan. Copyright 2011 Delaware Art Museum / Artists Rights Society (ARS), New York. See pages 131-151.

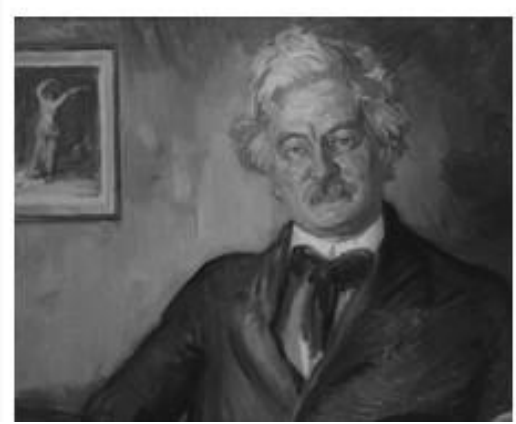

\section{http://ir.uiowa.edu/wwar/}




\section{SMARTech \\ Scholarly Materials And Research at Tech}

Georgia

Register

Advanced Search

Q Search:

tech Home - College of Liberal Arts - lyan Allen College (IAC) . Art History of Games Symposium

wse

I SMARTech

munities \&

ictions

ect

Collection

trol Pane

1

ster

\section{Art History of Games Symposium}

Search within this collection:

Go

Advanced Search

(See All Records)

Games, a creative form "older than culture," have served humanity in such diverse ways as entertainment, education, exercise, conflict resolution, ritual and self-expression. But not until the 20th century did games and the play experiences they provide start to be perceived as an art form as well. With nods to the past and future, and with an open acknowledgment of all the awkwardness, bravado and measured successes thus far, The Art History of Games seeks to more clearly articulate the importance of games as a form of art.

The Art History of Games was a three-day public symposium organized by Georgia Tech Digital Media and SCAD Atlanta, where members of the fields of game studies, art history and related areas of cultural studies gathered to investigate games as an art form. Leading game theorists and historians from around the world gathered in the High Museum of Art's Rich Auditorium on the campus of the Woodruff Arts Center, in midtown Atlanta.

All items in SMARTech are protected by copyright; they may be used for educational purposes with proper attribution. All other uses require the author's permission

Recent Submissions

06-Feb-2010 Keynote Panel Discussion: John Romero, Christiane Paul, Harvey Smith, Richard

06-Feb-2010

06-Feb-2010

05-Feb-2010

06-Feb-2010

mage Games

One Falls for Each of Us: The Prototyping of Tragedy

Play's the Thing: Games as fine art

Over games
Romero, John; Paul, Christiane: Smith, Harvey Lemarchand, Richard; Bogost, lan

Paul, Christiane

Brathwaite, Brenda

Pearce, Celia

Hawey, Auriea ; Samyn, Michael
Proceedings; Video

Proceedings; Video Proceedings; Video Proceedings; Video Proceedings; Video

\section{http://smartech.gatech.edu/handle/1853/33113}


THE UNIVERSITYof TENNESSEE GS KNOXVILLE

Trace Home

Search Trace

Search
in this collection $\checkmark$
Advanced Seard
Notify me of new items via email or RSS

Browse

Collections

Disciplines

Authors

\section{Tennessee Research and Creative Exchange}

Home > Cormac McCarthy Conference > Conference Proceedings

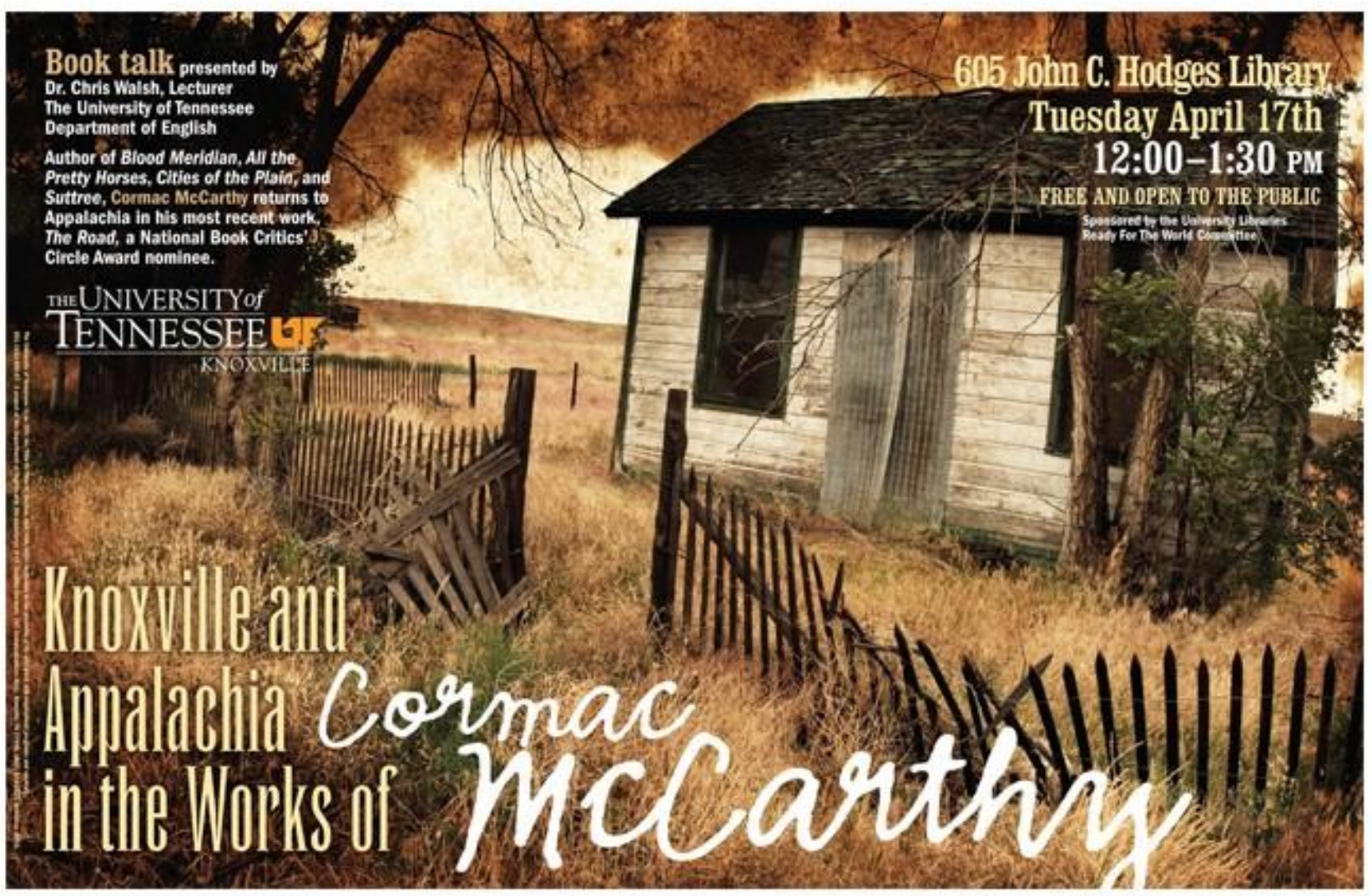

Browse the contents of Conference Proceedings:

Pre-Conference Talk (April 17, 2007)

Conference Program (April 26-28, 2007) 


\section{Search Trace}

Home > Cormac McCarthy Conference > Conference Proceedings > Conference Program (April 26-28, 2007)

\section{in this collection}

\section{Advanced Search}

Notify me of new items via email or RSS

\section{Browse}

\section{Collections}

Disciplines

Authors

\section{http://trace.tennessee.edu/utk mccarthy/FullSchedule/Conference/}

\section{Conference Program}

\section{7}

\section{Thursday, April 26th}

\begin{tabular}{|l|l}
\hline 2:00 PM & McCarthy's Sense of Ending \\
& $\begin{array}{l}\text { Jay Ellis, University of Colorado at Boulder } \\
\text { John C. Hodges Library } \\
\text { 2:00 PM - 3:30 PM }\end{array}$ \\
\hline 3:45 PM & Full Circle: "The Road" Rewrites "The Orchard Keeper" \\
& $\begin{array}{l}\text { Louis Palmer, Castieton State College } \\
\text { John C. Hodges Library } \\
\text { 3:45 PM - 5:00 PM }\end{array}$ \\
\hline
\end{tabular}

The Route and Roots of "The Road"

Wesley G. Morgan, University of Tennessee - Knoxville

John C. Hodges Library

3:45 PM - 5:00 PM

\section{Friday, April 27th}

9:00 AM

Compassionate Mccarthy? "The Road" and Schopenhauerian Ethics

Euan Gallivan, University of Nottingham

John C. Hodges Library

9:00 AM - 10:30 AM

Hospitality in Cormac McCarthy's "The Road"

Phillip Snyder, Brigham Young University

John C. Hodges Library 
Enter search terms:

\section{FACULTY BOOKS}

in this collection $v$

Search

Advanced Search

Notify me via email or RSS

\section{Browse}

Collections

Disciplines

Authors

\section{Authors}

Author FAQ

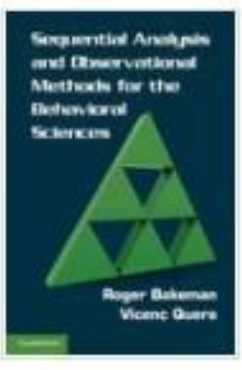

Sequential Analysis and Observational Methods for the Behavioral Sciences

Roger Bakeman and Vicenç Quera
Time Travel in the Latin American and Caribbean

Rudyard J. Aicocer 


\section{Bakers}

- Technical Services Librarians

- Public Services Librarians

- Archivists

- Library Administration

- Library Technology-Digital Initiatives Units 


\section{Bakers/Baking Process}

- Cataloger

- E-resources Librarian

Technical

Services

- Serials Librarian 


\section{THESES AND DISSERTATIONS}

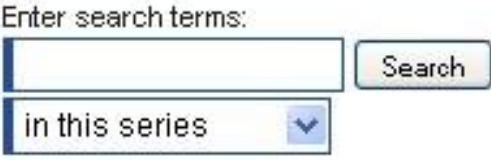

Advanced Search

Notify me via email or RSS

Theses/Dissertations from 2013

\& PDF Hitchcock and the Material Politics of Looking: Laura Mulvev, Rear Window, and PSycho, Tyler A. Theus

Theses/Dissertations from 2012

\& PDF THE POLITICAL IS PERSONAL: THE GEORGIA EQUAL RIGHTS AMENDMENT DEEATE IN PUELIC AND PRIVATE DISCOURSE, Haley Aaron

\& PDF THE PURSUIT OF HAPPINESS: THE STATE OF THE AMERICAN DREAM IN SUZAN-LORI PARKS'S TOPDOGMNDERDOG, Sabrina A. Abid

1. PDF Content and Contrastive Self-Knowledge, Vincent $G$. Abruzzo

$\triangle$ PDF Longitudinal Analysis of Risk Factors Affecting Reading Trajectories in Children Diagnosed with Pediatric Brain Tumors, Alyssa S. Ailion

$\angle$ PDF CHARACTERIZATION OF THE HEME UPTAKE PATHWNY PROTEINS FROM STREPTOCOCCUS PYOGENES AND CORYNEB,ACTERILM DIPHTHERIAE, Neval -. Akbas

$\angle$ PDF EXPLORING ISLAMIC GEOMETRIES, Maryam J. AI-Ainati

4 PDF Problem-Based Learning as a Teaching Method Versus Lecture-Based Teaching in Respiratory Therapy Education, Bandar M. A.lmasoudi

\section{Browse}

Collections

Disciplines

Authors

\section{Authors}

Author FAQ 


\section{Bakers/Baking Process}

- Tasks/Activities performed by Technical Services related to the management of an IR:

- Descriptive metadata, structural metadata

- Digitization standards

- Preservation operations

- Batch loading

Connell, T.H. and T. Cetwinski. "The Impact of Institutional Repositories on Technical Services." Technical Services Quarterly 27.4 (2010): 331-46. 


\section{Bakers/Baking Process}

- Re-use rather than re-create (avoid manual copying of data from one system to another)

- ILS

- Home grown system

IR 


\section{UNIVERSITY LIBRARY}

Journal Request Form

Spring 2012

1. What is the proposed title of the journal? The following may be helpful when determining the title of the journal: http://www.loc.gov/issn/basics/basics-whatsinaname.html

2. Provide a description of the journal including the aims \& scope.

3. Provide the name of the faculty member who will be responsible for and/or serve as the managing editor of the journal.

4. Provide a list of names of individuals who will serve on the editorial board. (The editorial board will be the body that oversees the editorial policies and manages the peer review procedures. At least one Georgia State University faculty member must be on the editorial board to help insure continuity.)

5. Do you have a logo? If so, you will need to provide a copy in .jpg, .png or .gif format.

6. How often will the journal come out? How will the issues be numbered? How will the order of the articles in an issue be determined?

7. Who can submit to the journal? What languages will be accepted?

8. What is the expected time frame for acceptance decision?

9. What citation style will authors be required to use? 


\section{Bakers/Baking Process}

- Digital Initiatives Librarian

- Director of Scholarly Communications

- Digital Collections and Metadata Lead

- Metadata and Electronic Resources Librarian

- Metadata and Collection Services Librarian

- Discovery/Metadata Librarian 


\section{Baking Process}

- Review metadata for ingestion into IR

- Knowledge of metadata standards

- Advises researchers on appropriate metadata schema for datasets

- Develop/maintain policies and best practices concerning metadata

- Experience with standards-based non-MARC metadata schemas such as Qualified Dublin Core, MODS, METS, and EAD

- Experience managing and promoting an IR with repository management software like DSpace

- Collaborate with library colleagues on appropriate metadata planning and implementation for exposing contents of the IR

- Set up metadata and records structures within the IR

- Provide support for the library institutional repository and depositing faculty content.

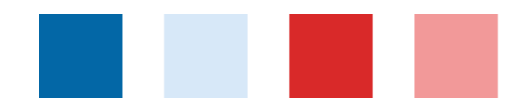




\section{Baking Process}

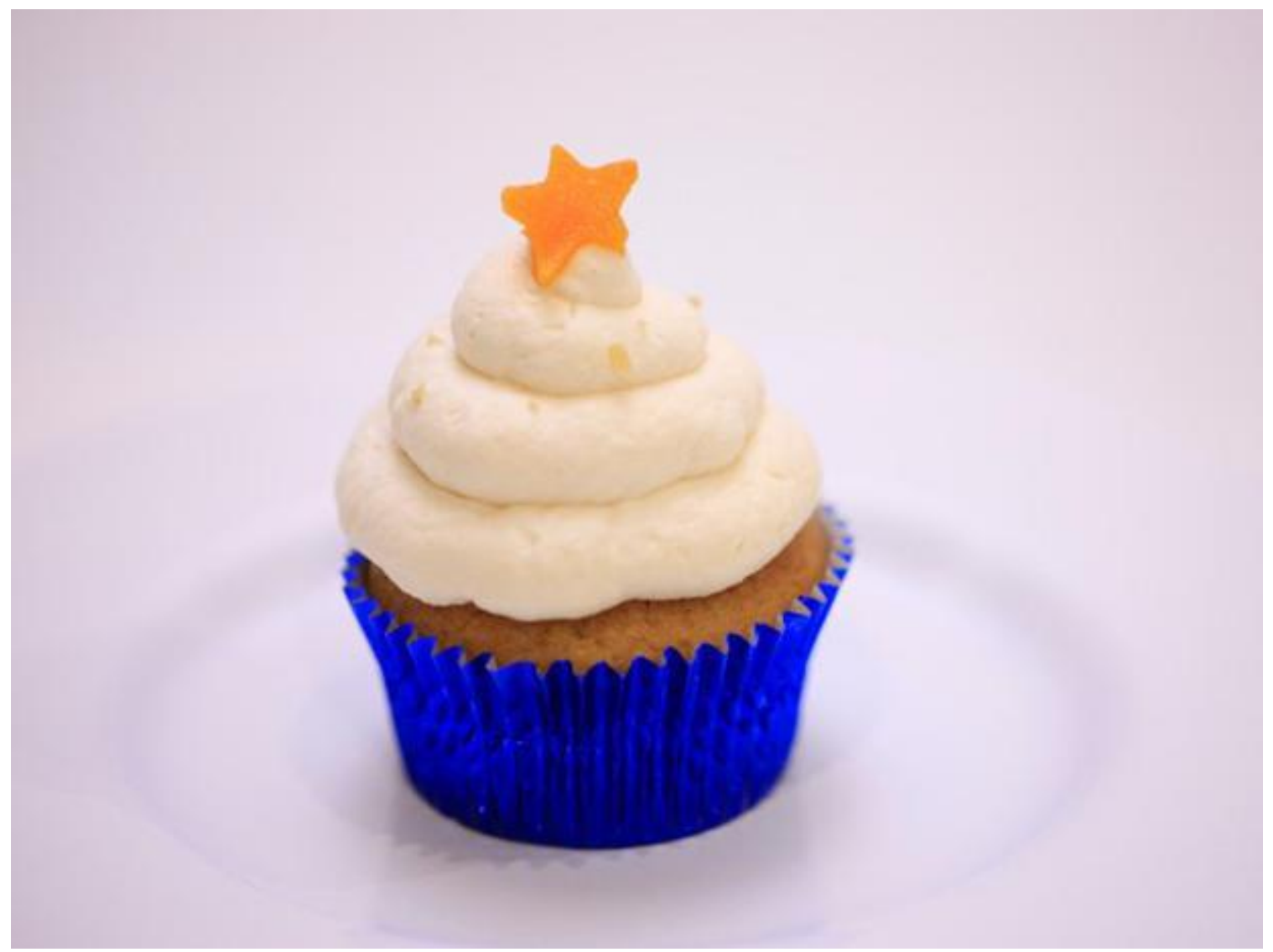

$\underset{\substack{\text { GeorgaState } \\ \text { University. }}}{\left(\int_{\text {UNIVERSITY }}^{(1 B R A R Y}\right.}$

$\underset{\text { University. }}{\left(\int_{\text {LI I R ARY }}\right.}$ 


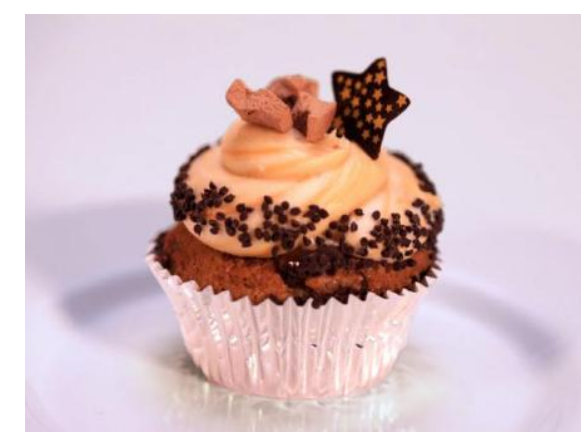

\section{"Virtual Tastings"}

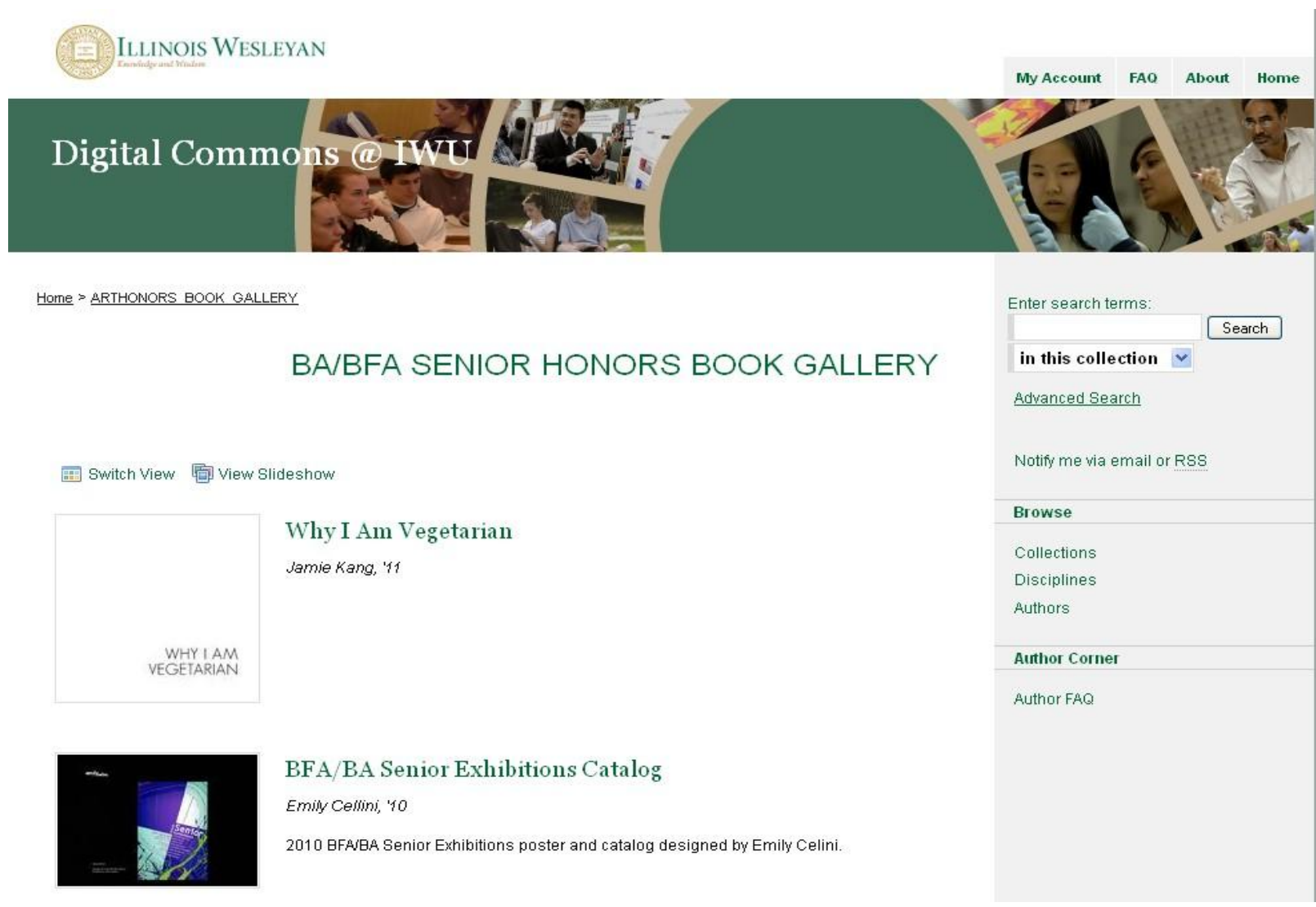

http://digitalcommons.iw u.edu/arthonors book $\mathrm{g}$ allery/

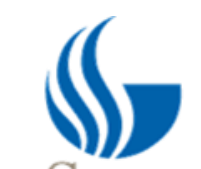

Emily Cellini, '10

2010 BFA 


\section{"Virtual Tastings"}

DIGITAL COMMONSQUM CAREY LAW

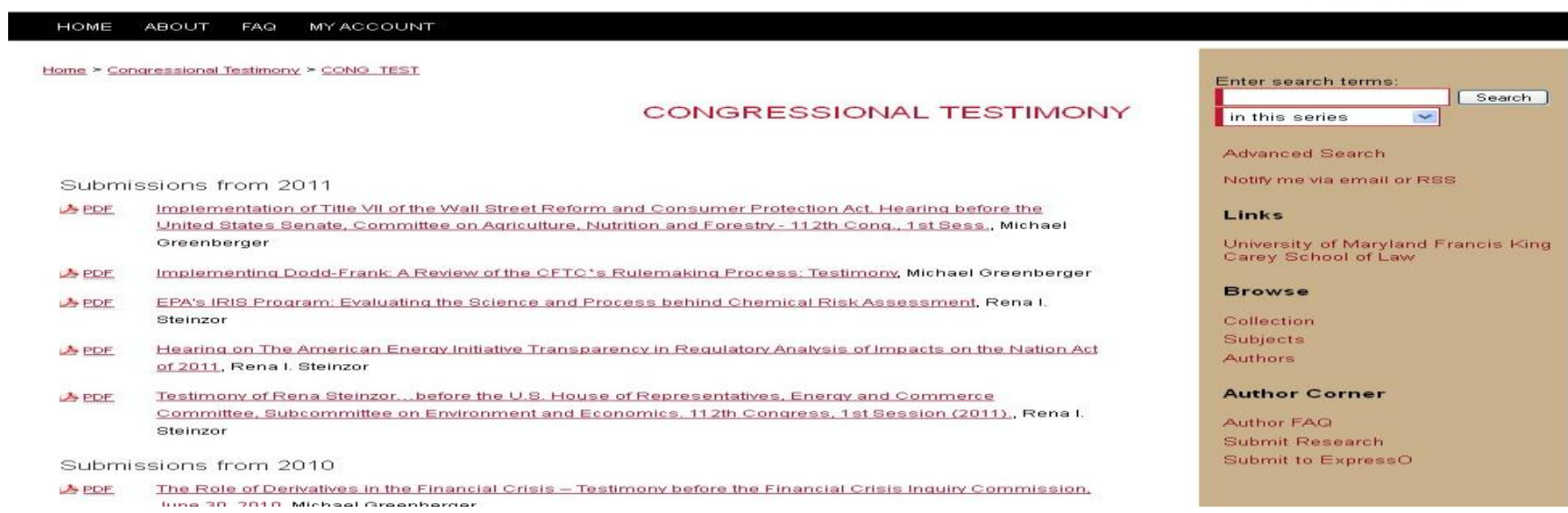

http://digitalcommons.law.umaryland.edu/cong test/ 


\section{"Virtual Tastings"}

....eCommons@Cornell...

eCommons@Cornell >

Browse Research \& Scholarship

Browse ecommons by:

" Centers, Institutes, and Programs

- Colleges, Departments, and Administrative Divisions

http://ecommons.lib rary.cornell.edu/inde $\underline{x . j s p}$

- Local and Regional Organizations

- Multimedia and videos

" Theses and Dissertations

= University Archives

(Centralized, searchable access to institutional digital resources maintained by Cornell University Archives)

Related Web Sites:

" Internet-First University Press (A new approach to scholarly publishing)

- Quantum Physics Made Easy (Three Lectures by Hans Bethe)

Other Cornell Digital Repositories:

" $\underline{\operatorname{arXiv}}$

" DiqitalCommons@ILR

- Cornell University Law Library NELLCO Repository

The Cornell University Library offers a wide variety of digital repositories and collections. For a complete list visit our Registry of Diqital Collections.

ABOUT THIS SITE

eCommons@Cornell is a service of the Cornell University Library that provides long-term access to a broad range of Cornell-related digital content of enduring value. It is open to anyone affiliated with Cornell University (faculty, staff, students, or groups/organizations) as a place to store, organize, preserve, index, and redistribute materials in digital formats that may be useful for educational, scholarly, research, or historical purposes. [more]

\section{GeorgaState | UNIVERSITY University.}


"The job of digital repositories is to ensure that the extremely valuable scholarly or creative products that have been paid for by the public or by donors are ultimately accessible to them, as well as to students, faculty and researchers everywhere."

--David Shulenberger, VP for Academic Affairs, Association of Public and Land-Grant Universities, 2006-2010

http://www.arl.org/sparc/meetings/ir08/closing keynote.shtml 


\section{Bibliography}

Connell, Tschera Harkness and Thomas Cetwinski. "The Impact of Institutional Repositories on Technical Services." Technical Services Quarterly 27.4 (2010): 331-46.

Crow, Raym. "The Case for Institutional Repositories: A SPARC Position Paper." ARL

223 (August 2002): 1-4 http://www.arl.org/newsltr/223/instrepo.html.

Lynch, Clifford A. "Institutional Repositories: Essential Infrastructure for Scholarship in the Digital Age." ARL 226 (February 2003): 1-7

http://www.arl.org/resources/pubs/br/br226/br226ir.shtml.

Walsh, Maureen P. "Repurposing MARC Metadata for an Institutional Repository: Working with Special Collections and University Press Monographs." Library Resources \& Technical Services 55.1 (2011): 33-44.

Walters, Tyler O. "Reinventing the Library - How Repositories are Causing Librarians to Rethink Their Professional Roles." portal: Libraries and the Academy 7.2 (2007): 213-25.

Ramirez, Marisa and Nancy Fallgren. "Making the Most of Your Descriptive Metadata: Planning, Transforming, and Re-using." Association for Library Collections and Technical Services. 24 March 2010 http://www.ala.org/alcts/confevents/upcoming/webinar/irs/032410meta. 